\title{
Osthole enhances antitumor activity and irradiation sensitivity of cervical cancer cells by suppressing ATM/NF-кB signaling
}

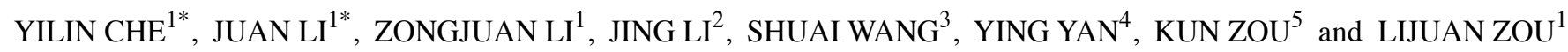 \\ ${ }^{1}$ Department of Radiotherapy Oncology, The Second Affiliated Hospital of Dalian Medical University, Dalian, \\ Liaoning 116027; ${ }^{2}$ Department of Cardiology, The First Affiliated Hospital of Dalian Medical University, Dalian, \\ Liaoning 116011; ${ }^{3}$ Department of Ophthalmology, The Second Affiliated Hospital of Dalian Medical University, Dalian, \\ Liaoning 116027; ${ }^{4}$ Department of Radiotherapy Oncology, The General Hospital of Shenyang Military Command, Shenyang, \\ Liaoning 110016; ${ }^{5}$ Department of Radiotherapy Oncology, The First Affiliated Hospital of Dalian Medical University, \\ Dalian, Liaoning 116011, P.R. China
}

Received March 3, 2018; Accepted June 15, 2018

DOI: 10.3892/or.2018.6514

\begin{abstract}
Osthole (7-methoxy-8-isopentenoxycoumarin) is an $\mathrm{O}$-methylated coumarin, originally extracted from Chinese herbal medicine. It has been demonstrated that osthole has antitumor effects in various cancer cells in vitro. The present study assessed the effects of osthole on the regulation of cervical cancer cell viability, apoptosis, and radiation sensitization. HeLa, $\mathrm{SiHa}, \mathrm{C}-33 \mathrm{~A}$ and CaSki cervical cancer cell lines were cultured and treated with osthole and/or irradiation and then subjected to 3-(4,5-dimethylthiazol-2-yl)-2,5-diphenyl-tetrazolium bromide cell viability, colony formation, apoptosis, acridine orange/ethidium bromide fluorescence staining, wound-healing, Transwell migration and invasion, immunofluorescence, Comet and western blot assays. The data showed that osthole dose-dependently reduced cervical cancer cell viability, proliferation, and migration and invasion, but induced apoptosis. At the protein level, osthole affected the expression
\end{abstract}

Correspondence to: Dr Lijuan Zou, Department of Radiotherapy Oncology, The Second Affiliated Hospital of Dalian Medical University, 467 Zhongshan Road, Dalian, Liaoning 116027, P.R. China

E-mail: lijuanzou1963@163.com

Dr Kun Zou, Department of Radiotherapy Oncology, The First Affiliated Hospital of Dalian Medical University, 222 Zhongshan Road, Dalian, Liaoning 116011, P.R. China

E-mail: kunzou29@126.com

*Contributed equally

Abbreviations: PBS, phosphate-buffered saline; MTT, 3-(4,5 -dimethylthiazol-2-yl)-2,5-diphenyltetrazolium bromide; EMT, epithelial-mesenchymal transition; DMSO, dimethyl sulfoxide; HPV, human papillomavirus; FACS, fluorescence-activated cell sorter; DAPI, 4',6-diamidino-2-phenylindole

Key words: cervical cancer, antitumor activity, osthole, radiosensitivity, apoptosis, epithelial-mesenchymal transition of cervical cancer cell epithelial-mesenchymal transition markers, which showed that the expression of E-cadherin was increased, whereas that of vimentin was decreased. Osthole treatment also sensitized cervical cancer cells to irradiation, showing increased DNA damage as assessed by the Comet assay, and inhibited nuclear factor $-\kappa \mathrm{B}$ signaling. In conclusion, osthole is an herbal agent that may offer potential for used as an adjuvant treatment for cervical cancer.

\section{Introduction}

Human cervical cancer presents a significant worldwide health burden, particularly in developing countries (1), and it accounted for $\sim 500,000$ new cases of cervical cancer cases and 250,000 cases of cancer-related mortality globally in 2012 (2). Human papillomavirus (HPV) infection is causally associated with the incidence rate of cervical cancer and, to date, there are two vaccines (Gardasil and Cervarix) available to prevent the majority of cervical cancer-associated HPV subtypes ( 16 and 18 subtypes accounting for $75 \%$ of cervical cancer cases) (2). Histologically, $\sim 80-85 \%$ of cervical cancer is squamous cell carcinoma and the remaining $15-20 \%$ is adenocarcinoma (3). Clinically, cervical cancer can be curably treated with surgery at the early stages of the disease or with radiation therapy and cisplatin-based chemotherapy at the later stages, or as adjuvant therapy following surgery (4). The prognosis of patients with cervical cancer primarily depends on the stage of the disease. For example, the 5-year survival rate for the earliest stage of invasive cervical cancer is $>90 \%$, whereas the 5-year survival rate for all other stages is $\sim 70 \%$ (1). However, the 5-year survival rate is only $25-35 \%$ for patients with stage III cervical cancer and $<15 \%$ for those with stage IV (1). Therefore, the development of novel therapies or agents is critical for effectively controlling the later stages of cervical cancer and improving survival rates.

Osthole (7-methoxy-8-isopentenoxycoumarin) is a monomer compound that is extracted from Cnidiummonnieri (L.) Cusson, which has been shown to have anti-proliferative, anti-inflammatory and anti-leishmanial effects $(4,5)$. This Traditional Chinese Medicine has been used for years clinically 
to treat different disorders, including allergies, inflammation, HIV infection and diabetes. It has been demonstrated that osthole has anti-metastatic and anti-proliferative effects in various types of human cancer. More specifically, osthole enhances tumor cell apoptosis, arrests cell cycle progression, and inhibits tumor cell migration (6-13). Furthermore, a previous study showed that osthole can enhance cisplatin antitumor activity in rhabdomyosarcoma cells (14) and another study reported that osthole prevented hepatocellular carcinoma (11). Together, these studies indicate the potential role of osthole in the treatment of human cancer, including cervical cancer.

In the present study, the antitumor activity of osthole in cervical cancer was investigated in vitro as a single agent or in combination with irradiation. The underlying molecular events of osthole treatment in cervical cancer cells were also investigated. This was expected to provide an initial assessment of osthole for treating cervical cancer.

\section{Materials and methods}

Cell lines and culture. HeLa, SiHa, C-33A and CaSki human cervical cancer cell lines were obtained from the American Type Culture Collection (ATCC; Manassas, VA, USA). The HeLa, SiHa and C-33A cells were cultured in Eagle's minimal essential medium (EMEM) and the CaSki cells were cultured in Dulbecco's modified Eagle's medium (DMEM), all of which were supplemented with $10 \%$ fetal bovine serum (FBS; Gibco; Thermo Fisher Scientific, Inc., Waltham, MA, USA), penicillin (100 U/ml, Gibco; Thermo Fisher Scientific, Inc.) and streptomycin $(100 \mu \mathrm{g} / \mathrm{ml}$, Gibco; Thermo Fisher Scientific, Inc.), and maintained in a humidified incubator with $5 \% \mathrm{CO}_{2}$ at $37^{\circ} \mathrm{C}$.

For radiation treatment, cells were grown and treated with or without osthole (see below for details) and then subjected to $6 \mathrm{~Gy}$ (the comet assay) or $10 \mathrm{~Gy}$ (western blot analysis) X-ray irradiation at a dose rate of $3.38 \mathrm{~Gy} / \mathrm{min}$ using X-320ix (Precision X-Ray, Inc., North Branford, CO, USA) at room temperature.

Tumor cell viability 3-(4,5-dimethylthiazol-2-yl)-2,5diphenyltetrazolium bromide solution (MTT) assay. The cells were seeded into 96 -well plates at a density of $1 \times 10^{4} /$ well and grown for $24 \mathrm{~h}$ and then treated with different concentrations of osthole $(0,40,80,120,160$ or $200 \mu \mathrm{M}$; Chengdu Must Bio-Technology Co., Ltd., Sichuan, China) for 24 or $48 \mathrm{~h}$ at $37^{\circ} \mathrm{C}$. At the end of each experiment, $5 \mathrm{mg} / \mathrm{ml} \mathrm{MTT}$ in phosphate-buffered saline (PBS) was added and the cells were cultured at $37^{\circ} \mathrm{C}$ for $4 \mathrm{~h}$. The cell culture supernatant was removed and $150 \mu \mathrm{l}$ dimethyl sulfoxide (DMSO) was added to dissolve the formazan crystals for $10 \mathrm{~min}$, following which the optical density was measured at $490 \mathrm{~nm}$ using a spectrophotometer (PerkinElmer, Inc., Waltham, MA, USA). The experiments were performed in triplicate and repeated at least three times. Data are summarized as the percentage of the control.

Tumor cell colony formation assay. The cells were seeded into 6 -well plates at a density of 1,000/well, grown overnight and then treated with different concentrations of osthole $(0,50,100$ or $200 \mu \mathrm{M}$ ) for 12 days. The culture medium was refreshed every other day. At the end of the experiments, the cells were stained with $1 \%$ crystal violet solution for $20 \mathrm{~min}$ at room temperature. Cell colonies with $\geq 50$ cells were counted using an inverted microscope (Leica Microsystems GmbH, Wetzlar, Germany). The experiments were performed in triplicate and repeated at least three times. Data are summarized as the percentage of the control.

Tumor cell apoptosis assay. The apoptotic rate of cells was measured using the fluorescence-activated cell sorter (FACS) following staining with the Annexin-V FITC kit (BD Pharmingen $^{\mathrm{TM}}$; BD Biosciences, San Diego, CA, USA). The cells were grown in 6-well plates and treated with or without osthole for $24 \mathrm{~h}$, and then collected for staining with the FITC-labeled Annexin V and PI kit according to the manufacturer's protocol. The cells were subsequently analyzed using the FACS Accuri C6 flow cytometer (Genetimes Technology Inc., Shanghai, China). The experiments were performed in triplicate and repeated twice. Data are summarized as the percentage of the control.

Acridine orange/ethidium bromide (AO/EB) fluorescence staining. The cells were seeded onto chamber slides (Corning Inc., Corning, NY, USA) and treated with $100 \mu \mathrm{M}$ of osthole for $24 \mathrm{~h}$. Following treatment, the cells were washed with ice-cold PBS to remove detached cells and then fixed in $95 \%$ ethanol for $15 \mathrm{~min}$. Following brief drying, the chamber slides were stained with $5 \mu \mathrm{l} \mathrm{AO} / \mathrm{EB}(50 \mu \mathrm{g} / \mathrm{ml})$, according to the manufacturer's protocol, and cell images were captured using a Leica DM 14000B microscope with digital camera (Leica Microsystems $\mathrm{GmbH}$ ). The experiments were performed in triplicate and repeated twice. Data are summarized as the percentage of the control.

Tumor cell scratch assay. The cells were grown to reach $90-95 \%$ confluency in 6-well plates. The cell monolayer was wounded using a sterile $100-\mu 1$ pipette tip and then washed with cell growth medium to remove the detached cells. The cells were cultured in serum-free medium and treated with osthole at different concentrations $(0,20$ or $40 \mu \mathrm{M})$ for $24 \mathrm{~h}$. Images of the wounded monolayer were captured at different time points using an inverted microscope (Olympus Corp., Tokyo, Japan). The experiments were performed in triplicate and repeated three times. Data are summarized as a percentage of the control.

Transwell tumor cell migration and invasion assays. The cells were grown and treated with osthole $(0,20$ or $40 \mu \mathrm{M})$ for $24 \mathrm{~h}$ and then suspended in cell solution, and $2 \times 10^{4}$ cells in serum-free EMEM were added to the upper insert of the Transwell chamber (Corning Inc.). The insert membrane was pre-coated with or without $50 \mu$ l Matrigel Matrix (1 mg/ml; Corning Inc.). EMEM supplemented with $20 \%$ FBS was added to the bottom of the Transwell plates, and the Transwell plates were incubated at $37^{\circ} \mathrm{C}$ for $24 \mathrm{~h}$. The tumor cells remaining on the upper side of the membrane were removed using a cotton swab, and tumor cells that invaded the reverse side of the membrane were fixed with $95 \%$ ethanol and stained with $1 \%$ crystal violet solution for $20 \mathrm{~min}$. 
Images were captured in five random microscopic fields at x200 magnifications using an inverted Olympus microscope (Olympus Corp.). The experiments were performed in triplicate and repeated twice. Data are summarized as a percentage of the control.

Immunofluorescence staining. The cells were seeded onto coverslips, treated with osthole $(0$ or $40 \mu \mathrm{M})$ for $24 \mathrm{~h}$ and then fixed in $4 \%$ paraformaldehyde for $10 \mathrm{~min}$ at room temperature. The cells were then permeabilized in $0.05 \%$ Triton X-100 in PBS for $10 \mathrm{~min}$ at room temperature and subsequently incubated with a monoclonal rabbit anti-E-cadherin (cat. no. 3195) or vimentin (cat. no. 5741) antibody at a dilution of 1:100, or a monoclonal rabbit anti-NF- $\mathrm{B}$ p65 (cat. no. 8242) at a dilution of $1: 200$ at $4^{\circ} \mathrm{C}$ overnight, all from Cell Signaling Technology, Inc. (Beverly, MA, USA). The following day, the cells were washed with PBS three times and then incubated with a secondary anti-rabbit IgG $(\mathrm{H}+\mathrm{L}), \mathrm{F}\left(\mathrm{ab}^{\prime}\right) 2$ fragment (Alexa Fluor ${ }^{\circledR} 555$ conjugated; cat. no. 4413; Vector Laboratories, Inc., Burlingame, CA, USA) at a dilution of 1:500) at the room temperature for $2 \mathrm{~h}$, and the cell nuclei were counterstained with 4',6-diamidino-2-phenylindole (DAPI; Vector Laboratories, Inc.). Cell images were then captured in five random microscopic fields using an Olympus fluorescence microscope (Olympus Corp.) (magnification, $\mathrm{x} 200)$. The experiments were performed in triplicate and repeated three times. Data are summarized as a percentage of the control.

Tumor cell Comet assay. Following the indicated treatment, the cervical cancer cells were collected, resuspended, and then loaded onto agarose coated glass slides, which were coated with $150 \mu 1$ of $0.5 \%$ agarose, at a density of $1.5 \times 10^{3}$ cells $/ \mu 1$. The slides were then soaked in a lysis buffer $(10 \mathrm{mM}$ Tris- $\mathrm{HCl}$, $2.5 \mathrm{M} \mathrm{NaCl}, 100 \mathrm{mM}$ EDTA, $1 \%$ Triton X-100 and 10\% DMSO) for $1 \mathrm{~h}$ and washed with neutralization buffer for $5 \mathrm{~min}$, each for three times. The slides were then placed into an iced-cold electrophoresis solution (300 $\mathrm{mM} \mathrm{NaOH}$ and $1 \mathrm{mM}$ EDTA) and subjected to $25 \mathrm{~V}$ at $300 \mathrm{~mA}$ electrophoresis for $25 \mathrm{~min}$. At the end of the experiments, the cells were stained with an ethidium bromide solution $(20 \mu \mathrm{g} / \mathrm{ml})$, and images were captured using an Olympus fluorescence microscope (Olympus Corp.). The numbers of cells with or without comet tails were counted and averaged. The experiments were performed in triplicate and repeated three times. Data are summarized as a percentage of the control.

Western blot analysis. Total cellular protein was extracted using a protein extraction kit (Thermo Fisher Scientific, Inc.), and protein concentration was measured using the BCA protein kit (Thermo Fisher Scientific, Inc.). The denatured protein samples of $30 \mu \mathrm{g}$ each were separated on $10 \%$ sodium dodecyl sulfate-polyacrylamide gel electrophoresis gels and electrophoretically transferred onto polyvinylidene fluoride membranes (BioTrace; Life Sciences, Port Washington, NY, USA). For western blot analysis, the membranes were blocked in $5 \%$ skimmed milk solution for $1 \mathrm{~h}$ and then incubated with a specific primary antibody at $4^{\circ} \mathrm{C}$ overnight. The following day, the membranes were washed with PBS-Tween-20 three times and then incubated with an anti-rabbit or mouse secondary antibody at the room temperature for $2 \mathrm{~h}$. The primary antibodies were rabbit monoclonal antibodies against Bcl-2 (cat. no. 3498), Bax (cat. no. 14796), cleaved caspase-3 (cat. no. 9664), cleaved caspase-9 (cat. no. 20750), vimentin (cat. no. 5741), N-cadherin (cat. no. 13116), E-cadherin (cat. no. 3195), $\beta$-catenin (cat. no. 8480), MMP-2 (cat. no. 40994), MMP-9 (cat. no. 13667), Phospho-ATM (Ser1981; cat.no. 13050), ATM (cat.no. 2873), Phospho-Histone H2A.X (Ser139; cat. no. 2577), Histone H2A.X (cat. no. 7631), NF-кB p65 (cat. no. 8242), Phospho-IKK $\alpha$ (Ser176)/IKK $\beta$ (Ser177) (cat. no. 2078), IKK $\alpha$ (cat. no. 2682), Phospho-NF- $\kappa \mathrm{B}$ p65 (Ser536; cat. no. 3033), NF-кB p65 (cat. no. 8242) and NF- $\mathrm{B} 1$ p105/p50 (cat. no. 12540; all from Cell Signaling Technology) and used at a dilution of 1:1,000, while the secondary antibody was an anti-rabbit IgG SA00001-2 (Proteintech, Wuhan, China) and used at a dilution of 1:5,000. The protein bands were subsequently visualized using chemiluminescence (Bio-Rad Laboratories, Inc., Hercules, CA, USA) and x-ray films.

Statistical analysis. Data are summarized as the mean \pm standard deviation (SD) and were statistically analyzed using GraphPad Prism software version 5.01 (GraphPad Software, Inc., La Jolla, CA, USA). Analysis of variance and Student's t-test were used to compare the values of the test and control samples. $\mathrm{P}<0.05$ was considered to indicate a statistically significant difference.

\section{Results}

Osthole inhibits cervical cancer cell viability and proliferation. To assess the anti-cervical cancer activity of osthole, a cell viability MTT assay was performed, and it was found that osthole reduced the viability of the four cervical cancer cell lines in a dose-dependent manner (Fig. 1A). In addition, the tumor cell colony formation assay showed that osthole treatment dose-dependently inhibited growth of cervical cancer cells (Fig. 1B). Morphologically, osthole treatment also reduced HeLa and SiHa cell-to-cell contact, and the osthole-treated tumor cells had more filopodia and cell layers (Fig. 1C).

Osthole induces cervical cancer cell apoptosis. The present study assessed whether the reduction in tumor cell viability was due to the induction of apoptosis using Annexin-V and FACS analyses. Osthole treatment significantly increased the apoptotic rate of the cells, compared with that of cells in the control group (Fig. 2A). To confirm the osthole-induced tumor cell apoptosis, HeLa cells were stained with AO/EB. In the control group, the uniform green staining showed normal morphology of cells, whereas osthole treatment induced early apoptosis of the tumor cells, which had condensed chromatin and red apoptotic bodies (Fig. 2B). At the gene level, osthole treatment increased the B-cell lymphoma 2 (Bcl-2)-associated $\mathrm{X}$ protein $(\mathrm{Bax}) / \mathrm{Bcl}-2$ ratio, and the levels of cleaved caspase- 3 and cleaved caspase- 9 in a dose-dependent manner, indicating that osthole activated the caspase-dependent pathway (Fig. 2C).

Osthole inhibits cervical cancer cell migration and invasion. A previous study revealed that osthole suppressed the invasion 
A
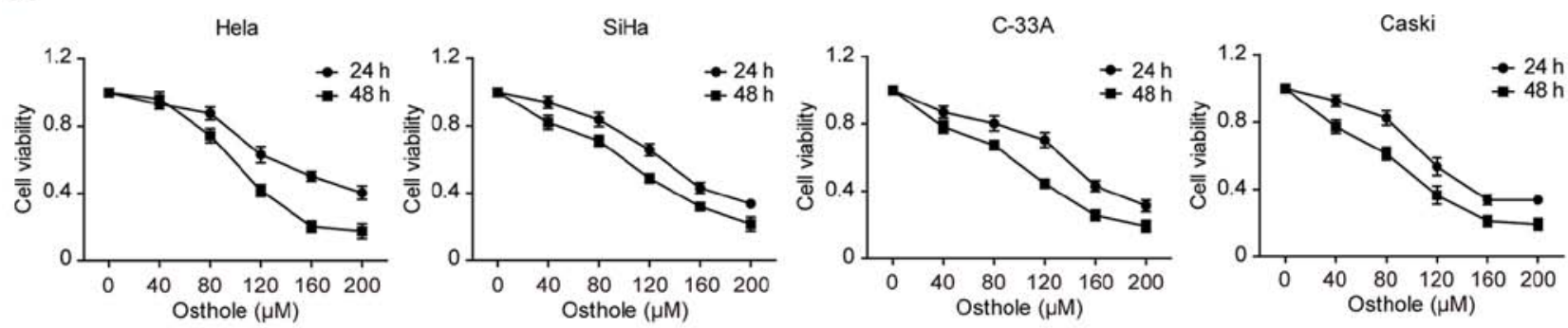

B

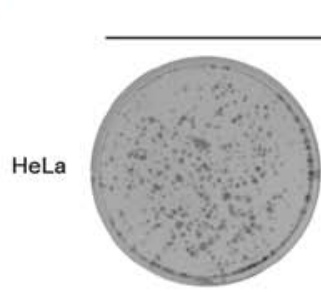

$0 \mu \mathrm{M}$

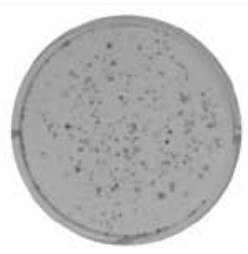

$50 \mu \mathrm{M}$

Osthole

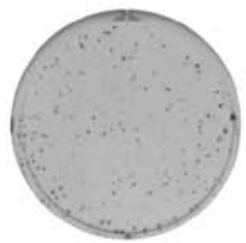

$100 \mu \mathrm{M}$

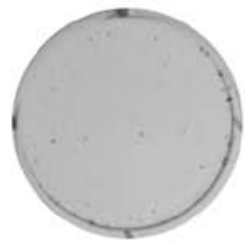

$200 \mu \mathrm{M}$

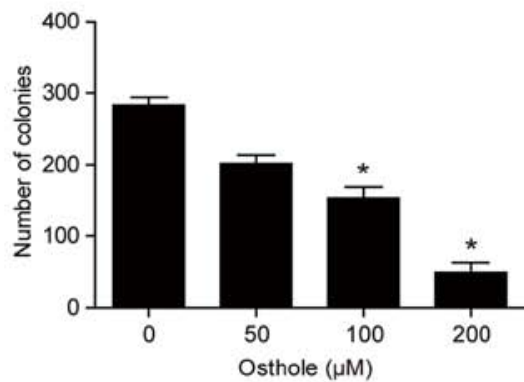

Osthole

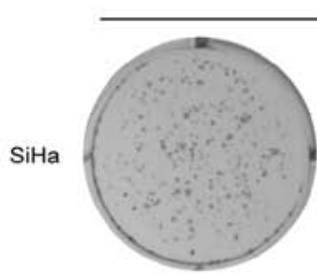

$0 \mu \mathrm{M}$

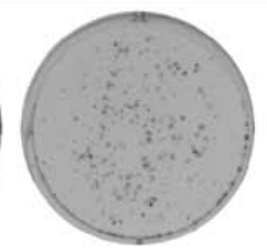

$50 \mu \mathrm{M}$

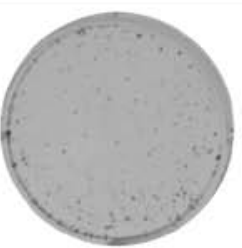

$100 \mu \mathrm{M}$

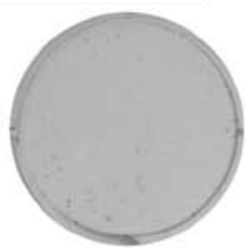

$200 \mu \mathrm{M}$

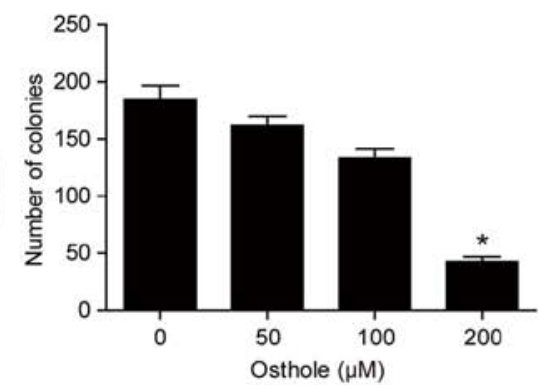

C

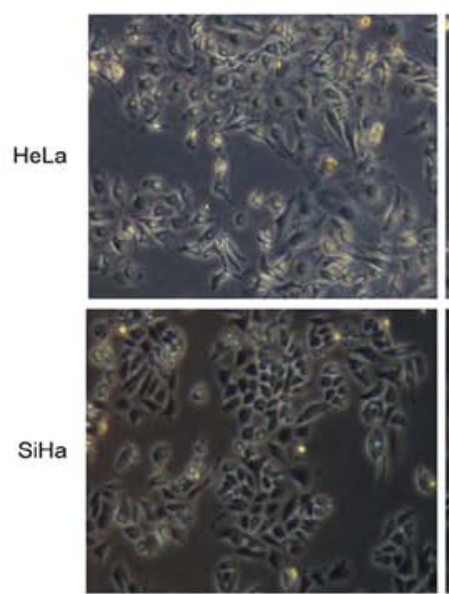

$0 \mu \mathrm{M}$
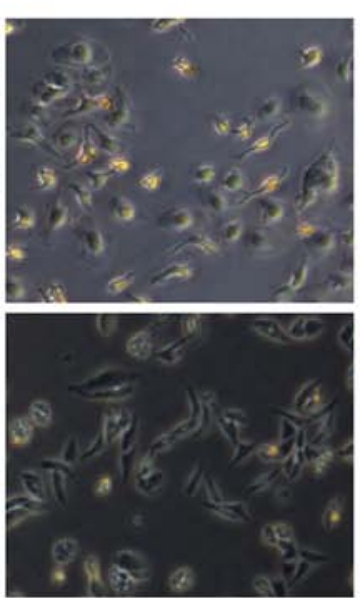

$50 \mu \mathrm{M}$
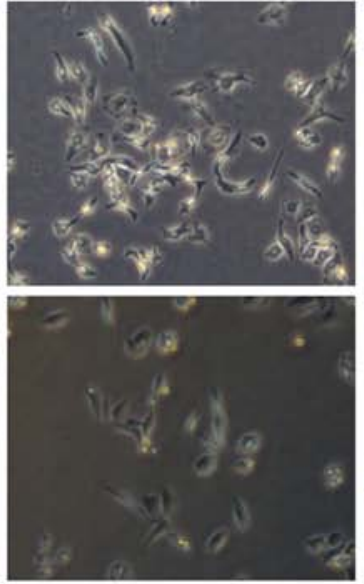

$100 \mu \mathrm{M}$
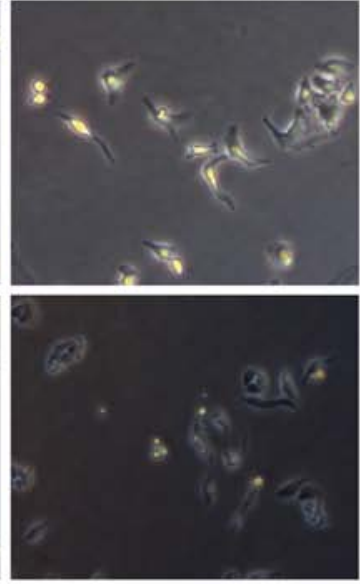

$150 \mu \mathrm{M}$

Figure 1. Osthole inhibits cervical cancer cell viability and proliferation. (A) MTT assay. HeLa, SiHa, C-33A, and CaSki human cervical cancer cells were treated with or without osthole $(0,40,80,120,160,200$ or $240 \mu \mathrm{M})$ for 24 or $48 \mathrm{~h}$ and then subjected to the cell viability MTT assay. Osthole suppressed cervical cancer cell viability in a dose-dependent manner. (B) Colony formation assay. Cells were grown and treated with $50 \mu \mathrm{M}$ osthole for up to 12 days and images were captured. Tumor cells with $\geq 50$ cells were counted and the data revealed that osthole inhibited colony formation of HeLa and SiHa cells in a dose-dependent manner. ${ }^{*} \mathrm{P}<0.05$ compared to the control cells. (C) Morphology. Tumor cells were grown and treated with or without osthole $(0,40,80$, $120,160,200$ or $240 \mu \mathrm{M}$ ) for $24 \mathrm{~h}$ and, and images were captured using an inverted microscope with an attached digital camera at $\mathrm{x} 200 \mathrm{magnification}$. MTT, 3-(4,5-dimethylthiazol-2-yl)-2,5-diphenyltetrazolium bromide.

capacity of lung cancer cells (13). In the present study, the effect of osthole on regulating cervical cancer cell migration and invasion was further examined using Transwell and scratch assays. The data showed that wound healing was significantly suppressed following osthole treatment in a dose-dependent manner (Fig. 3A). The Transwell assay data further supported this finding, as osthole suppressed the tumor cell migration and invasion capacity of the HeLa and SiHa cells (Fig. 3B).

Osthole suppresses levels of epithelial-mesenchymal transition (EMT)-related proteins in cervical cancer cells. Treatment of the cervical cancer cells with $50 \mathrm{mM}$ osthole 
A

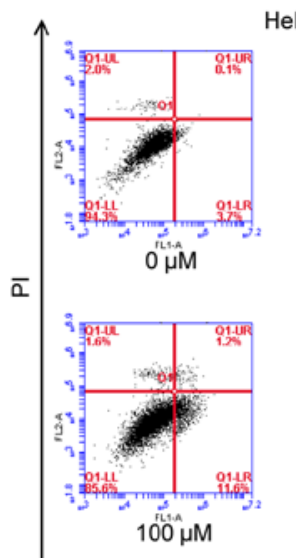

HeLa
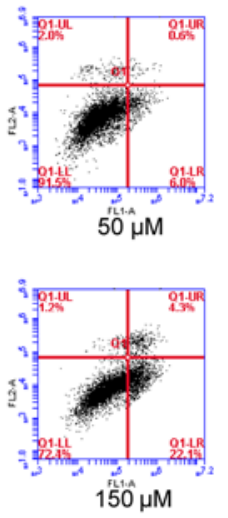

$\mathrm{SiHa}$
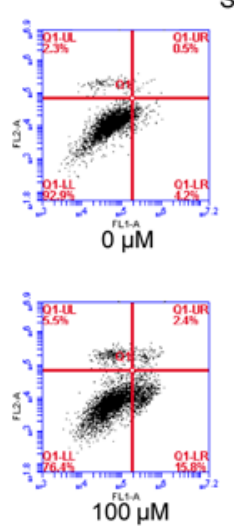
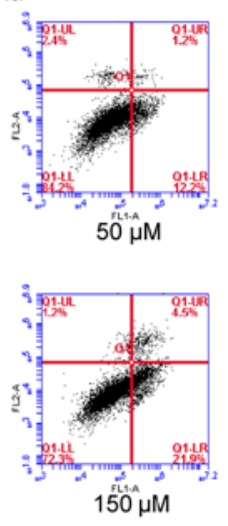

Annexin V

B

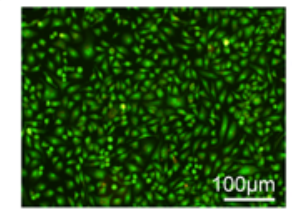

$0 \mu \mathrm{M}$

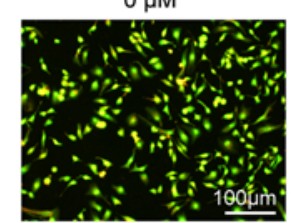

$100 \mu \mathrm{M}$

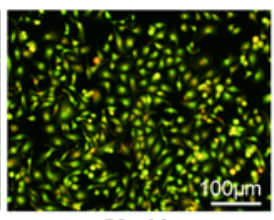
$50 \mu \mathrm{M}$

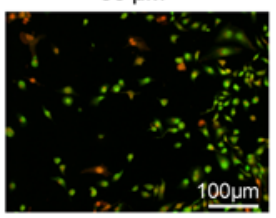

$150 \mu \mathrm{M}$

C
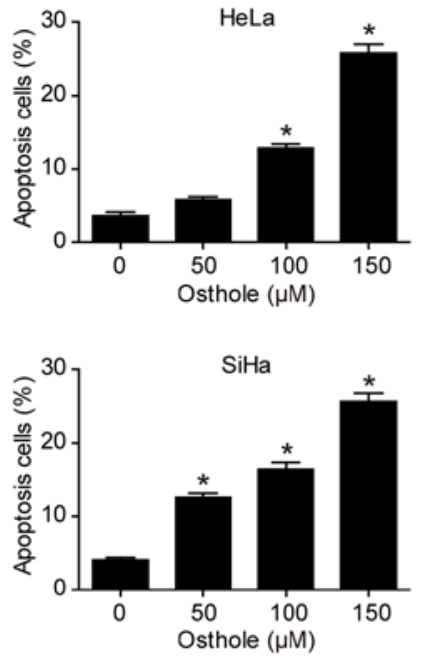
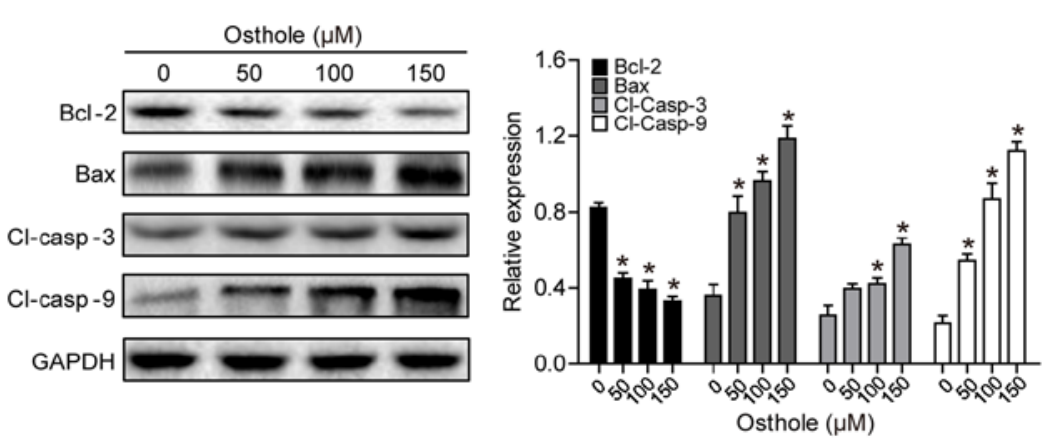

Figure 2. Osthole induces cervical cancer cell apoptosis. (A) HeLa and SiHa cells were grown and treated with osthole $(0,50,100$ or $150 \mu \mathrm{M})$ for $24 \mathrm{~h}$ and subjected to the apoptosis assay. (B) Tumor cell AO/EB fluorescence staining. HeLa cells were grown and treated with osthole $(0,50,100$ or $150 \mu \mathrm{M})$ for $24 \mathrm{~h}$ and subjected to staining. (C) Western blot analysis. Tumor cells were grown and treated with or without osthole (0, $40,80,120,160,200$ or $240 \mu \mathrm{M})$ for $24 \mathrm{~h}$ and then subjected to western blot analysis of Bcl-2, Bax, and cleaved caspase-3 and -9 proteins. * $\mathrm{P}<0.05$ compared to the control group. Bcl-2, B-cell lymphoma 2; Bax, Bcl-2-associated X protein; $\mathrm{Cl}$, cleaved.

increased the expression of E-cadherin but decreased the expression of Vimentin in the HeLa cells, as evidenced by the immunofluorescence analysis (Fig. 4A). This indicated that osthole suppressed cervical cancer cell EMT. The expression of other EMT biomarkers, including $\mathrm{N}$-cadherin, $\beta$-catenin, MMP-2 and MMP-9, were also analyzed (Fig. 4B and C), and the results suggested that osthole suppressed cervical cancer cell EMT. The osthole-induced suppression of cell adhesion proteins MMP-2 and MMP-9 in the HeLa and SiHa cells (Fig. 4C) also further support the results of the invasion and migration assays.

Osthole promotes cervical cancer cell DNA damage induced by irradiation. Radiotherapy is an important treatment option for locally advanced cervical cancer. A primary mechanism of irradiation is to induce tumor cell DNA damage (15). In the present study, a Comet assay was performed to assess the effects of osthole in combination with radiation on cervical cancer cells. The pretreatment of $\mathrm{HeLa}$ and $\mathrm{SiHa}$ cells with osthole $(50 \mu \mathrm{M})$ for $24 \mathrm{~h}$ and exposure to $6 \mathrm{~Gy}$ radiation markedly increased the irradiation-induced cervical cancer cell DNA damage, compared with that in the control cells (Fig. 5A). At the protein level, this treatment combination significantly inhibited phosphorylation of the ataxia telangiectasia mutated (ATM) and $\gamma \mathrm{H} 2 \mathrm{AX}$ proteins, whereas no significant changes in the levels of ATM and H2AX were observed (Fig. 5B). These results indicated that osthole inhibited the irradiation-induced DNA damage repair capacity of cervical cancer cells.

Osthole treatment in combination with irradiation inhibits $N F-\kappa B$ signaling. Previous studies have shown that NF- $\kappa \mathrm{B}$ signaling is involved in the regulation of tumor cell DNA damage (15) and that the osthole-induced suppression of lung cancer cell invasion capacity is mediated by suppression of the NF- $\mathrm{BB}$-induced expression of MMP-9 (13). Therefore, it was hypothesized that osthole-enhanced cervical cancer cell DNA damage and inhibited tumor cell migration and invasion are also be mediated by manipulating the $\mathrm{NF}-\kappa \mathrm{B}$ signaling pathway. The HeLa cells were treated with osthole $(0,50,100$ or $150 \mu \mathrm{M}$ ) for $24 \mathrm{~h}$ and western blot analysis was performed to detect key proteins of the $\mathrm{NF}-\kappa \mathrm{B}$ signaling pathway. It was found that osthole treatment significantly reduced the phos-

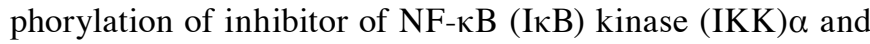
p65 proteins in the cytoplasm, but did not alter the levels of total IKK $\alpha$ or p65 (Fig. 6A). In addition, osthole treatment decreased nuclear protein expression of p50 and p65 (Fig. 6B). The subcellular localization of p65 protein in HeLa cells treated 
A
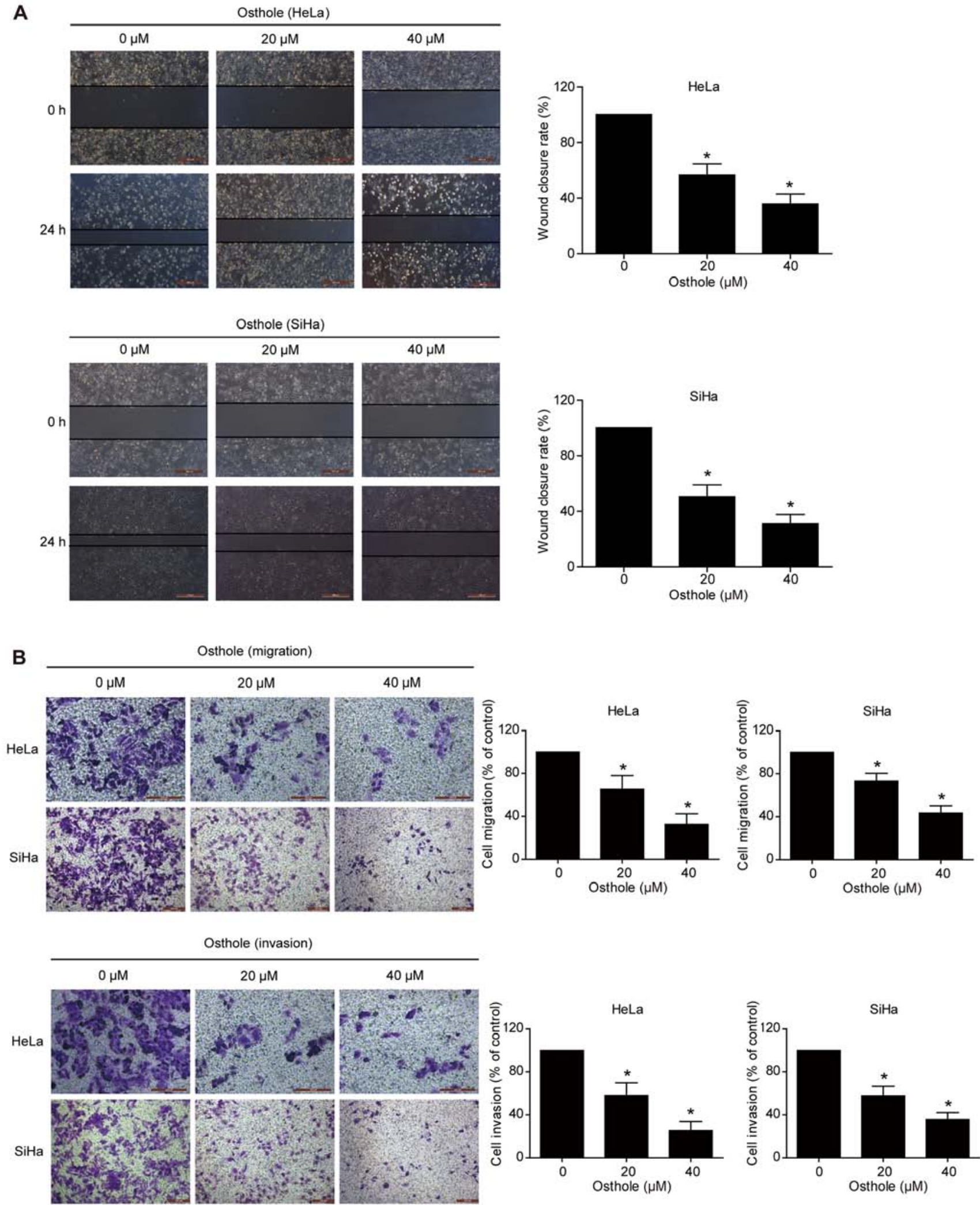

Figure 3. Osthole inhibits cervical cancer cell migration and invasion. (A) Tumor cell scratch assay. HeLa and SiHa cells were grown to $295-100 \%$ confluency, scraped with pipette tips, and treated with osthole $(0,20$ and $40 \mu \mathrm{M})$ for $24 \mathrm{~h}$. Wound healing was observed and images were captured. Images show that osthole inhibited HeLa and SiHa cell migration in a dose-dependent manner. (B) Transwell tumor cell migration and invasion assays. HeLa and SiHa cells were grown and treated with osthole $(0,20$ and $40 \mu \mathrm{M})$ for $24 \mathrm{~h}$ and then subjected to Transwell migration and invasion assays. Images show that osthole inhibited HeLa and SiHa cell migration and invasion compared with the control group (magnification, $\mathrm{x} 200)$. ${ }^{*} \mathrm{P}<0.05$ compared to the control cells.

with osthole $(0,50,100$ or $150 \mu \mathrm{M})$ was assessed by immunostaining and light microscopy, and the data were consistent with the results of the western blot analysis (Fig. 6C). These results suggested that osthole inhibited irradiation-induced DNA damage repair in HeLa cells through suppressing NF- $\kappa B$ signaling. 
A
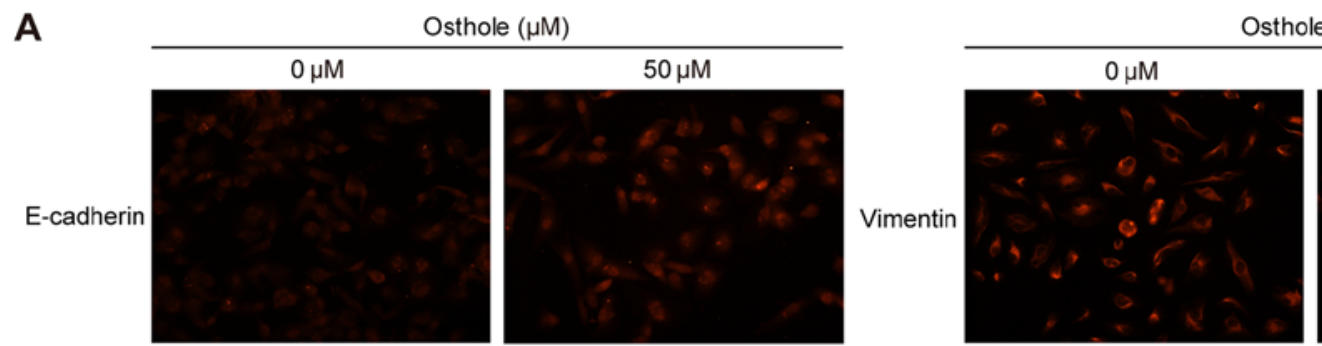

Osthole $(\mu \mathrm{M})$
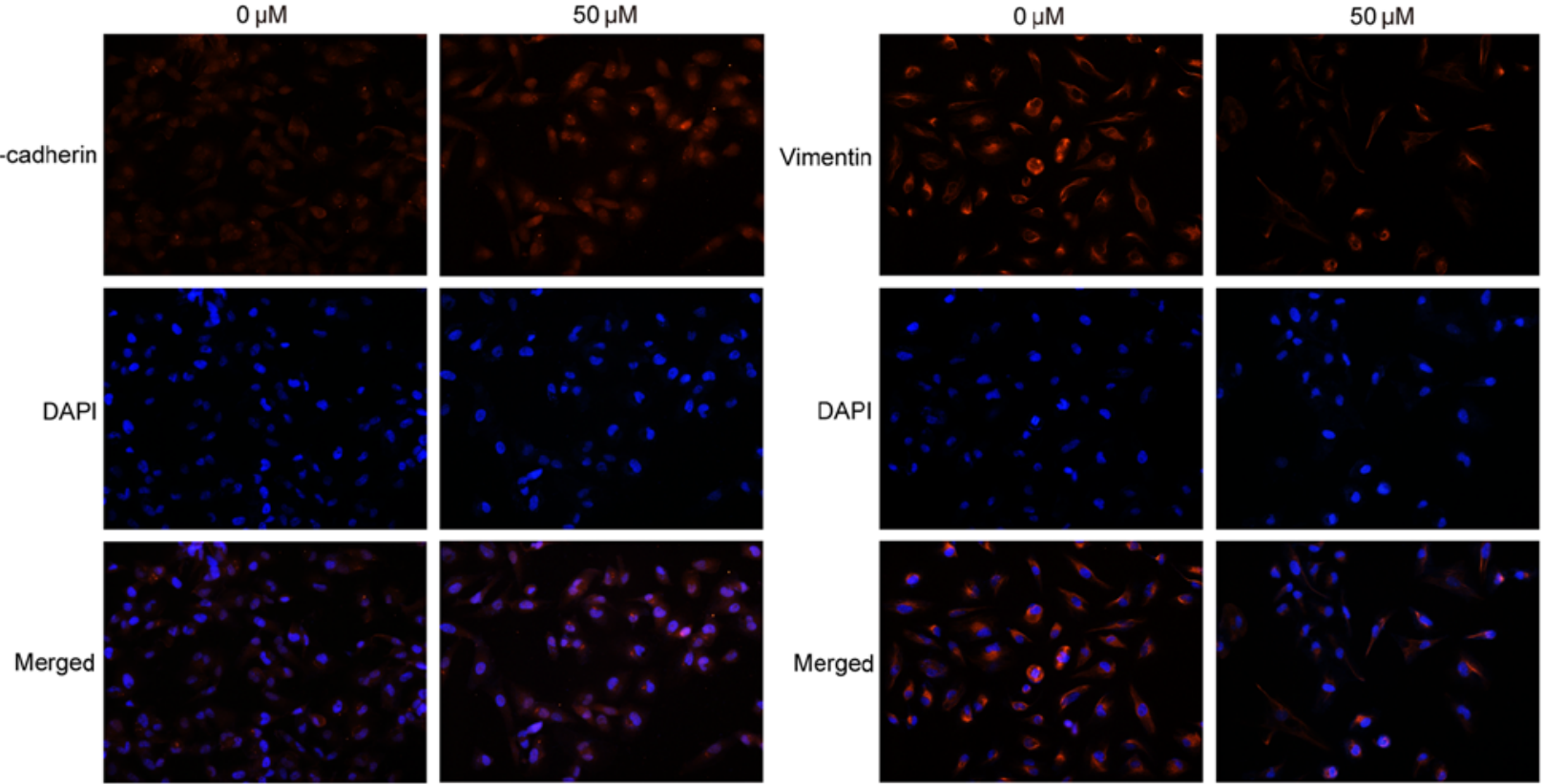

B
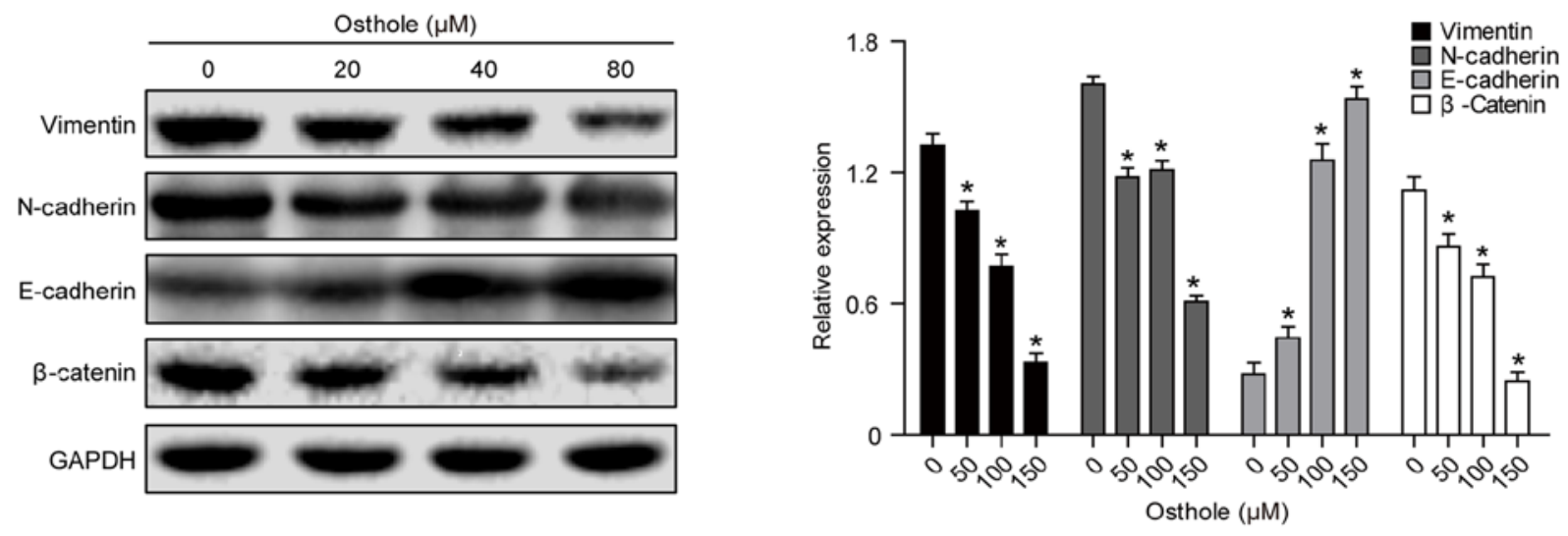

C
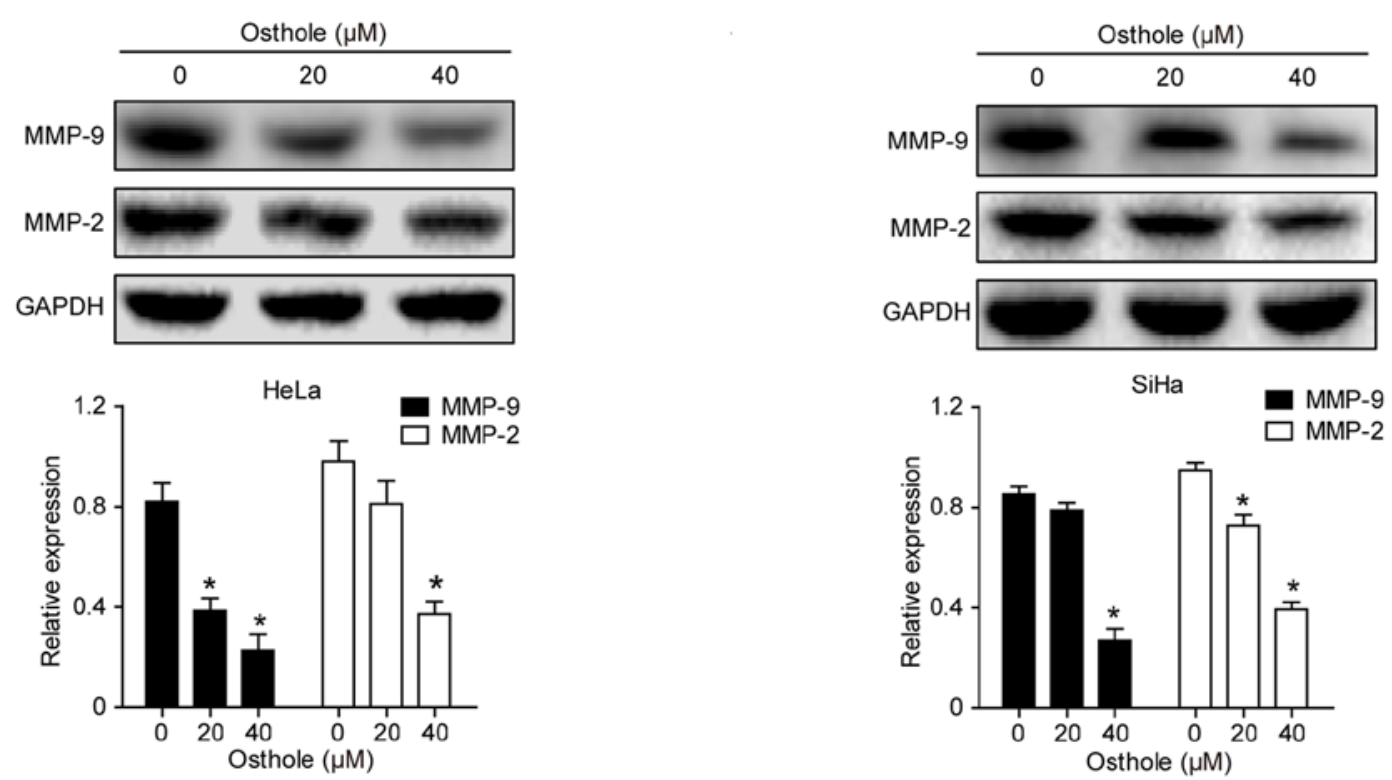

Figure 4. Osthole suppresses cervical cancer cell EMT. (A) Immunofluorescence analysis. HeLa cells were grown and treated with or without $50 \mu \mathrm{M}$ osthole for $24 \mathrm{~h}$ and then subjected to immunofluorescence analysis of EMT biomarkers (magnification, $\mathrm{x} 100$ ). The data showed that the expression of E-cadherin was increased, whereas that of vimentin was decreased in HeLa cells. (B) Western blot analysis. Tumor cells were grown and treated with or without osthole $(0,20$, 40 and $80 \mu \mathrm{M}$ ) for $24 \mathrm{~h}$ and then subjected to western blot analysis for detection of EMT biomarkers vimentin, N-cadherin, E-cadherin and $\beta$-catenin proteins. (C) Western blot analysis. HeLa and SiHa cells were grown and treated with or without osthole ( 20 and $40 \mu \mathrm{M})$ for $24 \mathrm{~h}$ and then subjected to western blot analysis detection of MMP-2 and MMP-9. Expression levels of MMP-2 and MMP-9 decreased in a dose-dependent manner with osthole exposure ("P $<0.05$, vs. control). EMT, epithelial-mesenchymal transition; DAPI, 4',6-diamidino-2-phenylindole; MMP, matrix metalloproteinase. 
A
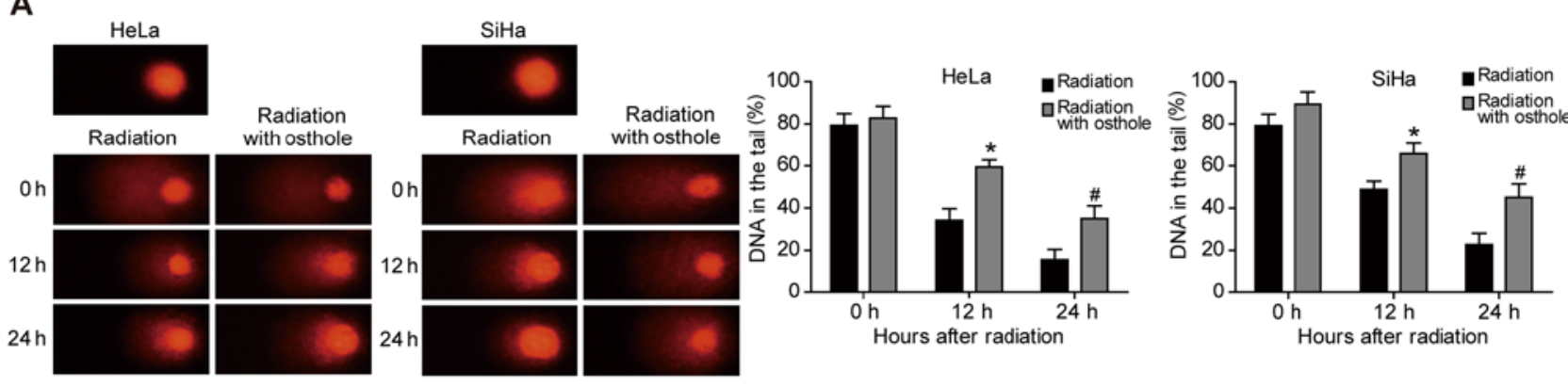

B
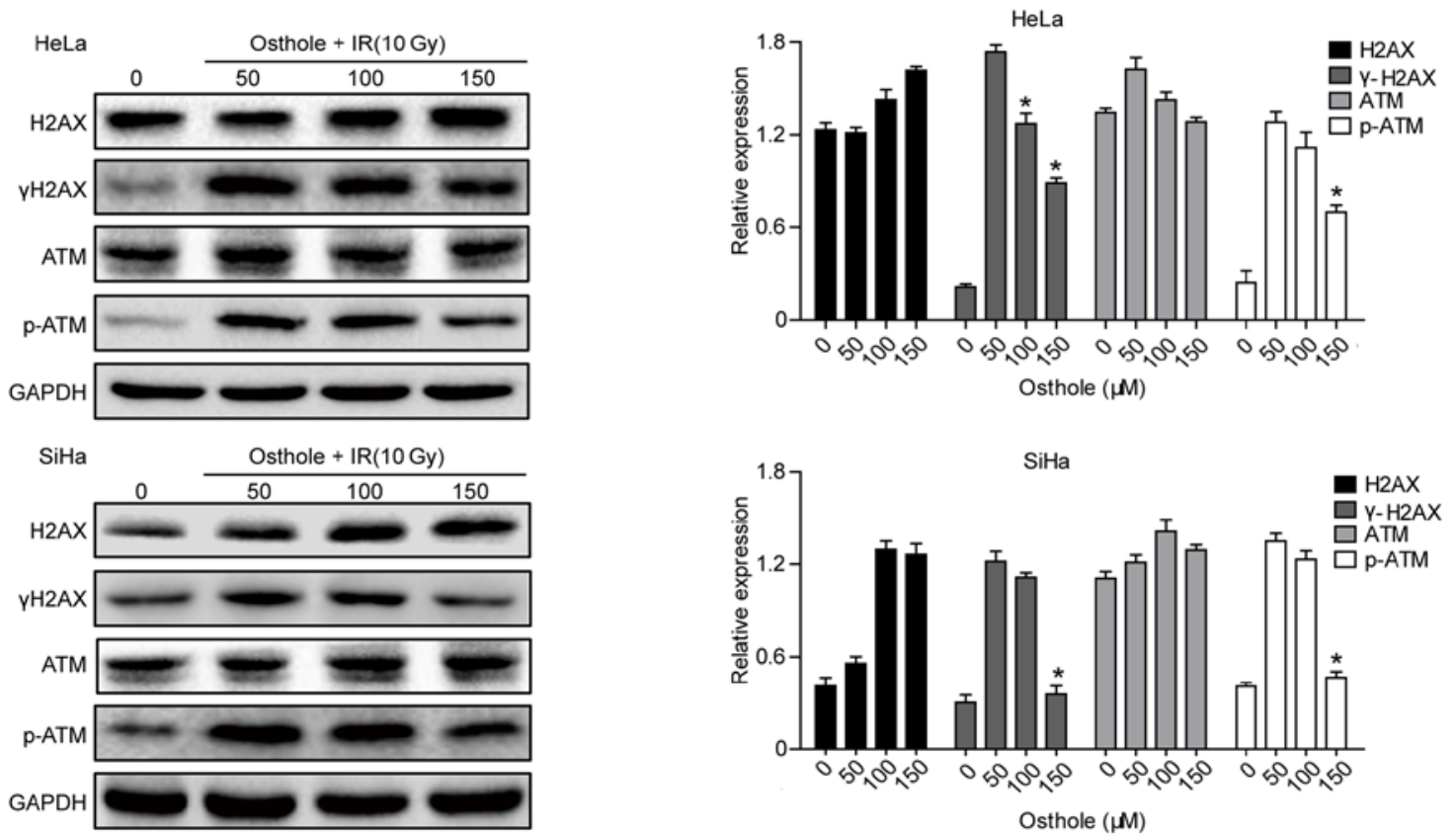

Figure 5. Osthole induces cervical cancer cell DNA damage induced by radiation. (A) Comet assay. HeLa and SiHa cells were grown and treated with $50 \mu \mathrm{M}$ osthole for $24 \mathrm{~h}$ and then subjected to $6 \mathrm{~Gy}$ irradiation and then subjected to the Comet assay. A total of 50 cells were randomly quantified from the images and the percentage of cell tail length was calculated. Data are summarized as the mean \pm standard deviation. ${ }^{*} \mathrm{P}<0.05$ compared to the control. (B) Western blot analysis. HeLa cells were grown and treated with osthole (50,100 or $150 \mu \mathrm{M})$ for $24 \mathrm{~h}$ and exposed to 10 Gy radiation and then subjected to western blot analysis for the detection of p-ATM, ATM, $\gamma \mathrm{H} 2 \mathrm{AX}$ and $\mathrm{H} 2 \mathrm{AX}$. ATM, ataxia telangiectasia mutated; p-, phosphorylated; IR, irradiation.

\section{Discussion}

In the present study, the antitumor activity of osthole in cervical cancer cells was assessed in vitro, and it was found that osthole treatment dose-dependently reduced tumor cell viability and proliferation, suppressed tumor cell migration and invasion, and induced apoptosis. Osthole treatment also modulated the expression of cervical cancer cell EMT markers, indicating that osthole inhibited tumor cell EMT. In addition, osthole treatment sensitized cervical cancer cells to irradiation and inhibited NF- $\mathrm{KB}$ signaling. Therefore, osthole may be further evaluated as an herbal agent for the adjuvant treatment of cervical cancer.

Osthole has been reported to induce apoptosis and have anti-proliferative activity in a variety of human cancer cells, including ovarian (16), lung (17), breast cancer (18) and hepatocellular carcinoma (19) cells. Osthole can inhibit the migration of MCF-7 breast cancer cells and the invasion of MDA-MB-231 breast cancer cells by suppressing MMP-2 and MMP-9 activity (8). The results of the present study extend the antitumor activity of osthole to cervical cancer cells.
It is known that the induction of tumor cell apoptosis is a crucial component of anticancer therapeutic agents. Osthole treatment significantly increased early and late apoptosis of cervical cancer cells. The present study demonstrated that the osthole-induced cervical cancer cell apoptosis was mediated by modulating the expression of activity of Bcl-2, Bax, caspase- 3 and caspase- 9 . Caspase- 3 and caspase- 9 are major factors in the apoptotic process, whereas Bcl-2, in contrast to Bax, is an anti-apoptotic protein in the mitochondrial apoptosis pathway (20). The data obtained in the present study showed that treatment of cervical cancer cell lines with osthole increased the protein expression of Bax, cleaved caspase- 3 and caspase- 9 and decreased the expression of $\mathrm{Bcl}-2$, indicating that osthole may be further evaluated as an anti-cervical cancer agent.

Tumor cell EMT is an important event during normal cell transformation into malignant cells and cancer metastasis (21). Morphologically, epithelial cells transform to mesenchymal cell phenotypes, which is accompanied by a loss of cell polarization, cell-cell adhesion, and increased migratory and invasive properties. EMT is essential in 
A
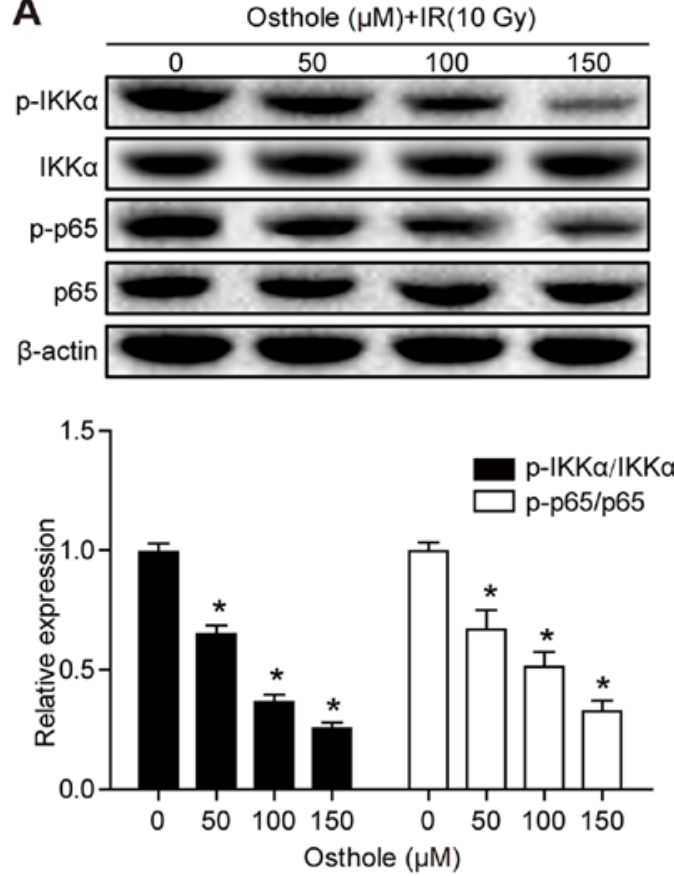

B
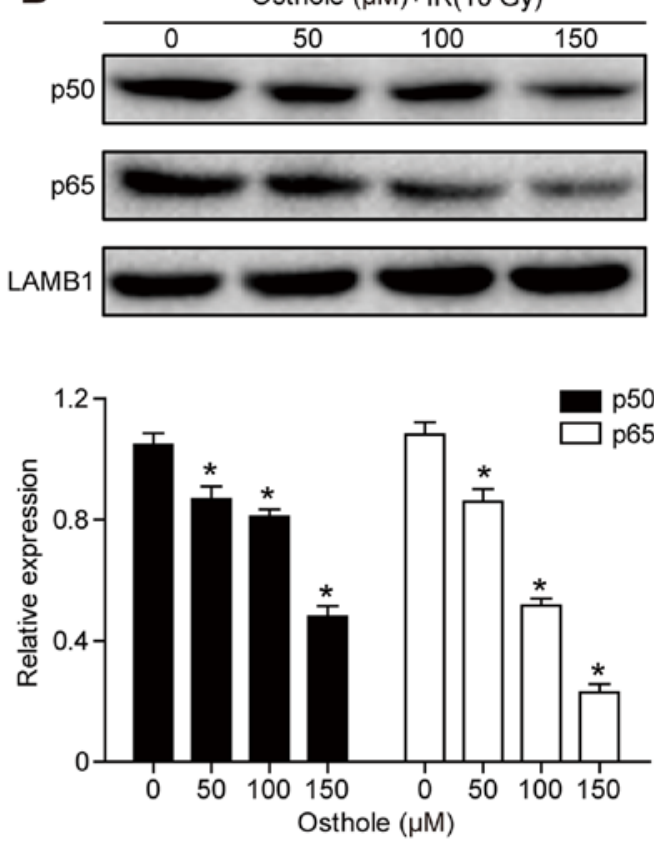

C

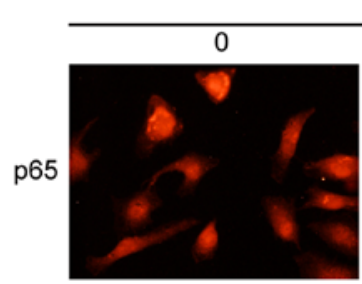

Osthole $(\mu M)+I R(10 G y)$
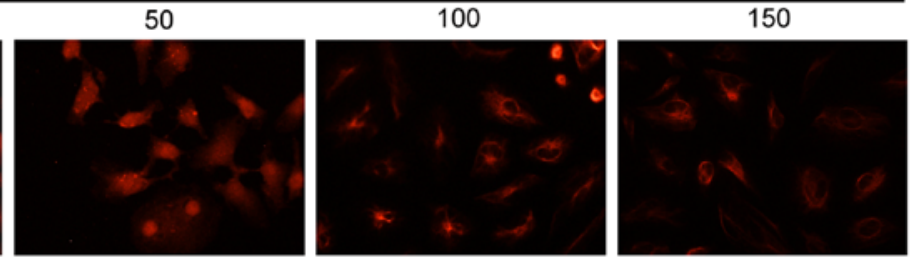

DAP
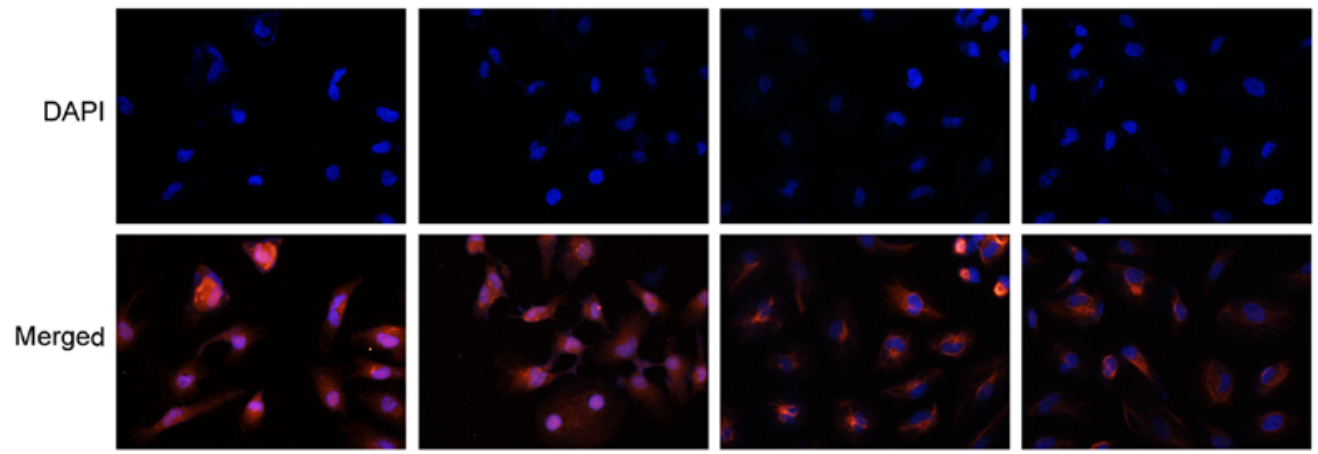

Figure 6. Osthole promotes NF- $\mathrm{B}$ signaling in radiation-induced cervical cancer cell DNA damage. HeLa cells were grown and treated with osthole (50, 100 or $150 \mu \mathrm{M}$ ) for $24 \mathrm{~h}$ and exposed to $10 \mathrm{~Gy}$ radiation. Cytoplasmic and nuclear proteins of HeLa cells were separately extracted for western blot analysis of key proteins in the NF- $\kappa$ B signaling pathway, including (A) IKK $\alpha$, p-IKK $\alpha$, p65, p-p65 and (B) p50. (C) Subcellular localization of p65 in HeLa cells was examined by analysis with a fluorescence microscope (magnification, $\mathrm{x} 50$ ). All results are expressed as the mean \pm standard deviation ("P<0.05, vs. control). $\mathrm{NF}-\kappa \mathrm{B}$,

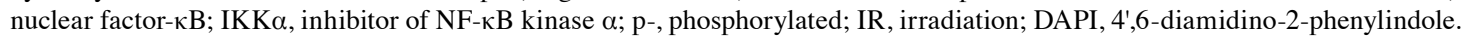

embryonic development, wound healing, cancer development and metastasis (21). Molecularly, EMT induces multiple biochemical changes to promote a mesenchymal phenotype (22). These changes impart migratory capacity, invasiveness, elevated resistance to apoptosis, and production of extracellular matrix (23). The changes include the downregulation of epithelial proteins, including E-cadherin and $\beta$-catenin, and the upregulation of mesenchymal proteins, including $\mathrm{N}$-cadherin and vimentin (24). In addition, the expression of different MMPs facilitates cell mobility, and the increased expression of MMP-2 and MMP-9 is considered to be important in cancer metastasis (25). A previous study demonstrated that cervical cancer with an EMT phenotype was associated with an increased risk of tumor progression, invasion, and metastasis (26). In the present study, it was shown that osthole treatment significantly reduced cervical cancer cell migration and invasion, and at the gene level, osthole upregulated epithelial markers (E-cadherin and $\beta$-catenin) and downregulated mesenchymal markers ( $\mathrm{N}$-cadherin and vimentin) and MMP-2 and MMP-9, consistent with the hypothesis that osthole inhibits cervical cancer cell EMT.

Locally advanced stages of cervical cancer are usually treated with chemotherapy and/or a combination of external beam radiation therapy and brachytherapy (27). However, $30-40 \%$ of patients do not respond well to these standard treatments, due to tumor cell resistance to radiotherapy (28). 


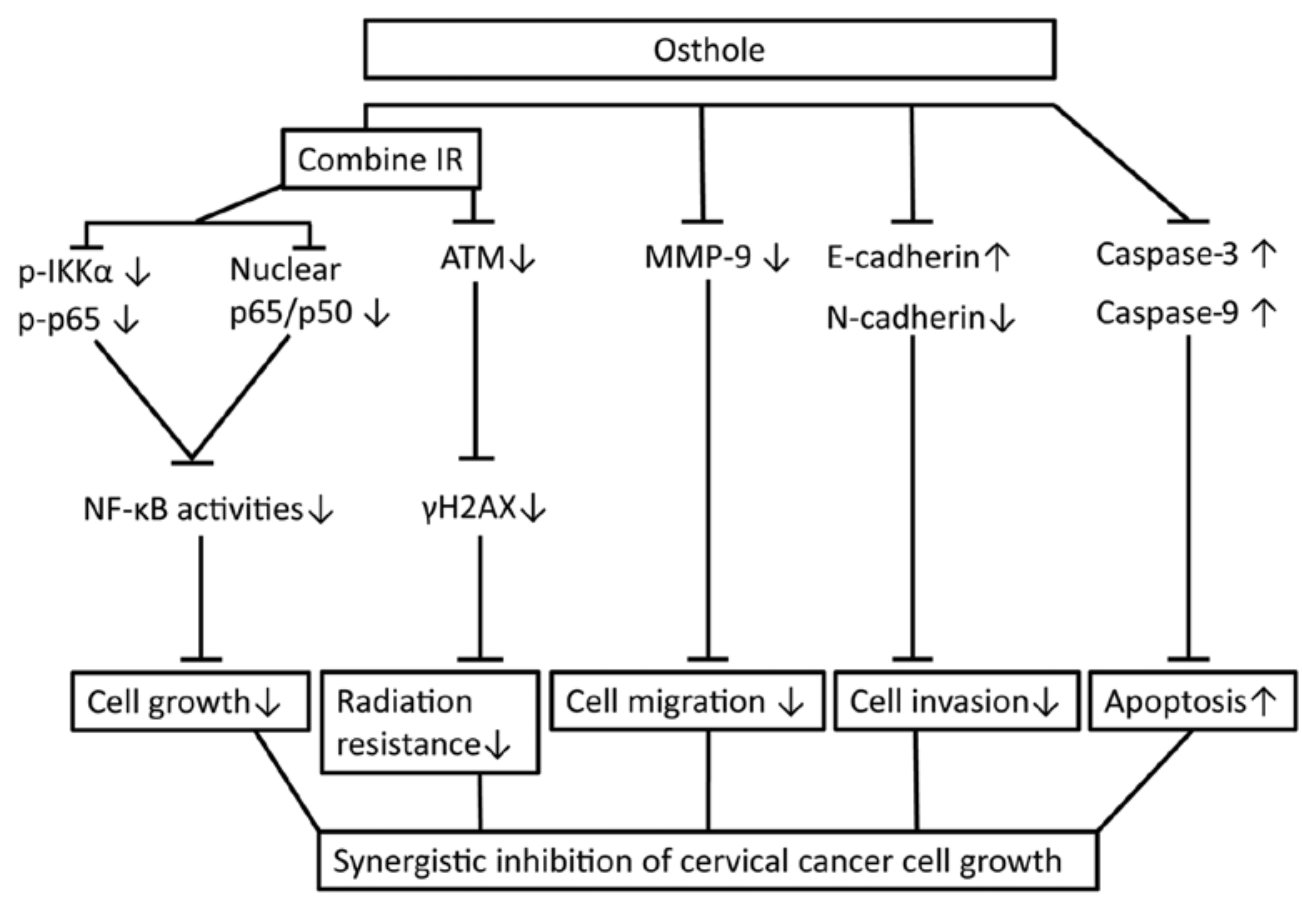

Figure 7. Osthole sensitization of radiation in inhibition of cervical cancer cell viability by targeting multiple signaling pathways. Cervical cancer cells were grown and treated with osthole in combination with radiation. Combination treatment suppressed the protein expression of vimentin, N-cadherin, MMP-2 and MMP-9, induced the cleavage of pro-apoptotic caspase, inhibited the phosphorylation of $\gamma \mathrm{H} 2 \mathrm{AX}$, IKK $\alpha$ and p65 proteins by ATM, and promoted the

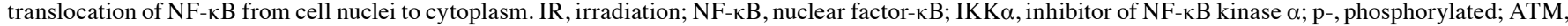
ataxia telangiectasia mutated; MMP, matrix metalloproteinase.

Therefore, the present study examined the effect of osthole on the sensitization of cervical cancer cells to radiotherapy. It was found that osthole co-treatment with radiation enhanced DNA damage in cervical cancer cells and inhibited DNA damage repair. During DNA damage repair, the ATM kinase is activated when cells suffer DNA double-strand breaks, and phosphorylated (p)-ATM regulates cell cycle checkpoints by phosphorylating p53 at Ser15, and activates checkpoint kinase 2 (CHK2) by phosphorylating CHK2 at Thr68 (29). Histone $\mathrm{H} 2 \mathrm{AX}$ phosphorylation is among the earliest responders to DNA double-strand breaks (30), which is activated by the ATM-induced phosphorylation of $\gamma \mathrm{H} 2 \mathrm{AX}$ (31). The data obtained in the present study support the findings that osthole inhibits p-ATM following radiation, enhancing the radiosensitivity of cervical cancer cells in vitro.

Finally, the present study also demonstrated that osthole attenuated the activation of IKK $\alpha$ and I $\mathrm{B} \alpha$, and decreased the translocation of p50/p65 into the cell nucleus, which further supports data from a previous study showing that osthole inhibited the NF- $\mathrm{NB}$-mediated expression of MMP-9, lung cancer cell migration and invasion (13). Activation of the $N F-\kappa B$ pathway occurs in irradiated tumor cells, and the activation of $N F-\kappa B$ has been shown to induce cancer cell resistance to the genotoxic anticancer therapeutic agent, cisplatin (32). However, further investigation is required to better understand the role of the NF- $\kappa \mathrm{B}$ pathway in cervical cancer.

In conclusion, the present study initially assessed the anti-cervical cancer activity of osthole in vitro and confirmed the dose-dependent effects of osthole on reducing cervical cancer cell proliferation, migration and invasion, and the induction of apoptosis by suppressing tumor cell EMT and radiation resistance. The findings also reveal a molecular mechanism by which osthole suppresses ATM and the NF- $\kappa$ B pathway (Fig. 7). The safety of osthole has been investigated, and the no-obvious adverse-effect level (NOAEL) of osthole is considered to be $<5 \mathrm{mg} / \mathrm{kg}$ in male and female rats. To validate the safety and efficacy of osthole, randomized, controlled trials with an adequate sample size are required, according to a previous study (33). Further investigations are also required to define the exact mechanism underlying the effect of osthole in cervical cancer.

\section{Acknowledgements}

Not applicable.

\section{Funding}

The present study was supported in part by a grant from the National Natural Science Foundation of China (no. 81473452).

\section{Availability of data and materials}

All supporting data and materials are available within the article.

\section{Authors' contributions}

YC and JL performed experiments; ZL and JL and SW analyzed data; YY, LZ and KZ conceived and designed the experiments; YC wrote the manuscript. All authors read and approved the manuscript and agree to be accountable for all 
aspects of the research in ensuring that the accuracy or integrity of any part of the work are appropriately investigated and resolved.

\section{Ethics approval and consent to participate}

Not applicable.

\section{Patient consent for publication}

Not applicable.

\section{Competing interests}

The authors declare that they have no competing interests.

\section{References}

1. Ginsburg O, Bray F, Coleman MP, Vanderpuye V, Eniu A, Kotha SR, Sarker M, Huong TT, Allemani C, Dvaladze A, et al: The global burden of women's cancers: A grand challenge in global health. Lancet 389: 847-860, 2017.

2. Torre LA, Bray F, Siegel RL, Ferlay J, Lortet-Tieulent J and Jemal A: Global cancer statistics, 2012. CA Cancer J Clin 65 87-108, 2015.

3. Lee MY and Shen MR: Epithelial-mesenchymal transition in cervical carcinoma. Am J Transl Res 4: 1-13, 2012.

4. Zimecki M, Artym J, Cisowski W, Mazol I, Włodarczyk M and Gleńsk M: Immunomodulatory and anti-inflammatory activity of selected osthole derivatives. Z Naturforsch C 64: 361-368, 2009.

5. Hao Y and Liu Y: Osthole alleviates bleomycin-induced pulmonary fibrosis via modulating angiotensin-converting enzyme 2/angiotensin-(1-7) axis and decreasing inflammation responses in rats. Biol Pharm Bull 39: 457-465, 2016.

6. Jiang G, Liu J, Ren B, Tang Y, Owusu L, Li M, Zhang J, Liu L and $\mathrm{Li} \mathrm{W}$ : Anti-tumor effects of osthole on ovarian cancer cells in vitro. J Ethnopharmacol 193: 368-376, 2016.

7. Ding D, Wei S, Song Y, Li L, Du G, Zhan H and Cao Y: Osthole exhibits anti-cancer property in rat glioma cells through inhibiting PI3K/Akt and MAPK signaling pathways. Cell Physiol Biochem 32: 1751-1760, 2013.

8. Yang D, Gu T, Wang T, Tang Q and Ma C: Effects of osthole on migration and invasion in breast cancer cells. Biosci Biotechnol Biochem 74: 1430-1434, 2010.

9. Wu C, Sun Z, Guo B, Ye Y, Han X, Qin Y and Liu S: Osthole inhibits bone metastasis of breast cancer. Oncotarget 8 : 58480-58493, 2017.

10. Chou SY, Hsu CS, Wang KT, Wang MC and Wang CC: Antitumor effects of Osthol from Cnidium monnieri: An in vitro and in vivo study. Phytother Res 21: 226-230, 2007.

11. Okamoto T, Kobayashi T and Yoshida S: Chemical aspects of coumarin compounds for the prevention of hepatocellular carcinomas. Curr Med Chem Anticancer Agents 5: 47-51, 2005.

12. Yang LL, Wang MC, Chen LG and Wang CC: Cytotoxic activity of coumarins from the fruits of Cnidium monnieri on leukemia cell lines. Planta Med 69: 1091-1095, 2003.

13. Kao SJ, Su JL, Chen CK, Yu MC, Bai KJ, Chang JH, Bien MY, Yang SF and Chien MH: Osthole inhibits the invasive ability of human lung adenocarcinoma cells via suppression of NF- $\kappa \mathrm{B}$-mediated matrix metalloproteinase-9 expression. Toxicol Appl Pharmacol 261: 105-115, 2012.

14. Jarzab A, Łuszczki J, Guz M, Skalicka-Woźniak K, Hałasa M, Smok-Kalwat J, Polberg K and Stepulak A: Combination of osthole and cisplatin against rhabdomyosarcoma TE671 cells yielded additive pharmacologic interaction by means of isobolographic analys. Anticancer Res 38: 205-210, 2018.

15. Small W Jr, Bacon MA, Bajaj A, Chuang LT, Fisher BJ, Harkenrider MM, Jhingran A, Kitchener HC, Mileshkin LR, Viswanathan AN, et al: Cervical cancer: A global health crisis. Cancer 123: 2404-2412, 2017.
16. Lin VC, Chou CH, Lin YC, Lin JN, Yu CC, Tang CH, Lin HY and Way TD: Osthole suppresses fatty acid synthase expression in HER2-overexpressing breast cancer cells through modulating Akt/mTOR pathway. J Agric Food Chem 58: 4786-4793, 2010.

17. Xu X, Zhang Y, Qu D, Jiang T and Li S: Osthole induces G2/M arrest and apoptosis in lung cancer A549 cells by modulating PI3K/Akt pathway. J Exp Clin Cancer Res 30: 33, 2011.

18. Dien PH, Nhan NT, Le Thuy HT and Quang DN: Main constituents from the seeds of Vietnamese Cnidium monnieri and cytotoxic activity. Nat Prod Res 26: 2107-2111, 2012.

19. Zhang L, Jiang G, Yao F, He Y, Liang G, Zhang Y, Hu B, Wu Y, Li Y and Liu H: Growth inhibition and apoptosis induced by osthole, a natural coumarin, in hepatocellular carcinoma. PLoS One 7: e37865, 2012

20. Yao C, Cao X, Fu Z, Tian J, Dong W, Xu J, An K, Zhai L and Yu J: Boschniakia rossica polysaccharide triggers laryngeal carcinoma cell apoptosis by regulating expression of $\mathrm{Bcl}-2$, Caspase-3, and P53. Med Sci Monit 23: 2059-2064, 2017.

21. Lamouille S, Xu J and Derynck R: Molecular mechanisms of epithelial-mesenchymal transition. Nat Rev Mol Cell Biol 15: 178-196, 2014.

22. Samatov TR, Tonevitsky AG and Schumacher U: Epithelial-mesenchymal transition: Focus on metastatic cascade, alternative splicing, non-coding RNAs and modulating compounds. Mol Cancer 12: 107, 2013.

23. Cruz-Solbes AS and Youker K: Epithelial to Mesenchymal transition (EMT) and endothelial to mesenchymal transition (EndMT): Role and implications in kidney fibrosis. Results Probl Cell Differ 60: 345-372, 2017

24. Thiery JP, Acloque H, Huang RY and Nieto MA: Epithelial-mesenchymal transitions in development and disease. Cell 139: 871-890, 2009.

25. Verma RP and Hansch C: Matrix metalloproteinases (MMPs) Chemical-biological functions and (Q)SARs. Bioorg Med Chem 15: 2223-2268, 2007.

26. LeeMY,ChouCY,Tang MJandShenMR:Epithelial-mesenchymal transition in cervical cancer: Correlation with tumor progression, epidermal growth factor receptor overexpression, and snail up-regulation. Clin Cancer Res 14: 4743-4750, 2008.

27. Moreno-Acosta P, Gamboa O, Sanchez de Gomez M, Cendales R, Diaz GD, Romero A, Balart Serra J, Conrado Z, Levy A, Chargari C and Magné N: IGF1R gene expression as a predictive marker of response to ionizing radiation for patients with locally advanced HPV16-positive cervical cancer. Anticancer Res 32: 4319-4325, 2012.

28. Yang J, Yue JB, Liu J and Yu JM: Repopulation of tumor cells during fractionated radiotherapy and detection methods (Review). Oncol Lett 7: 1755-1760, 2014.

29. Matsuoka S, Rotman G, Ogawa A, Shiloh Y, Tamai K and Elledge SJ: Ataxia telangiectasia-mutated phosphorylates Chk2 in vivo and in vitro. Proc Natl Acad Sci USA 97: 10389-10394, 2000.

30. Nambiar DK, Rajamani P, Deep G, Jain AK, Agarwal R and Singh RP: Silibinin preferentially radiosensitizes prostate cancer by inhibiting DNA repair signaling. Mol Cancer Ther 14: 2722-2734, 2015

31. Zhao J, Guo Z, Pei S, Song L, Wang C, Ma J, Jin L, Ma Y, He R, Zhong J, et al: pATM and $\gamma \mathrm{H} 2 \mathrm{AX}$ are effective radiation biomarkers in assessing the radiosensitivity of ${ }^{12} \mathrm{C}^{6+}$ in human tumor cells. Cancer Cell Int 17: 49, 2017.

32. Ahmed KM and Li JJ: NF-kappa B-mediated adaptive resistance to ionizing radiation. Free Radic Biol Med 44: 1-13, 2008.

33. Shokoohinia Y, Jafari F, Mohammadi Z, Bazvandi L, Hosseinzadeh L, Chow N, Bhattacharyya P, Farzaei MH, Farooqi AA, Nabavi SM, et al: Potential anticancer properties of osthol: A comprehensive mechanistic review. Nutrients 10: pii: E36, 2018.

This work is licensed under a Creative Commons Attribution-NonCommercial-NoDerivatives 4.0 International (CC BY-NC-ND 4.0) License. 